\title{
The pitch canker fungus, Fusarium circinatum: implications for South African forestry
}

\author{
RG MitchelI ${ }^{1 *}$, ET Steenkamp ${ }^{2}$, TA Coutinho ${ }^{2}$ and MJ Wingfield ${ }^{2}$ \\ 1 York Timbers, Tree Breeding Division, Private Bag X518, Sabie 1260, South Africa \\ ${ }^{2}$ Department of Microbiology and Plant Pathology, Forestry and Agricultural Biotechnology Institute (FABI), \\ University of Pretoria, Pretoria 0002, South Africa \\ *Corresponding author, e-mail: gmitchell@york.co.za
}

Fusarium circinatum, the causal agent of pitch canker of mature pines and root/collar rot of pine seedlings/cuttings, has resulted in large-scale losses to pine forestry in various parts of the world. The disease caused by this fungus is now regarded as one of the most important threats to pine plantations by a pathogen. Fusarium circinatum was first discovered in South Africa in 1990 where it infected Pinus patula seedlings in a nursery. Subsequently, the pathogen spread to pine nurseries in all other parts of the country, where it affects several Pinus species. Fusarium circinatum then appeared in the field where it has resulted in large-scale mortality of mostly young $P$. patula seedlings after planting. Pitch canker first appeared on mature $P$. radiata in 2006 and sporadic outbreaks of the disease have occurred subsequently on this species and on $P$. greggii in the western, southern and north-eastern Cape. Pinus patula is the most important softwood species grown in South Africa, comprising $50 \%$ of all softwoods planted, and is highly susceptible to $F$. circinatum. The pathogen, therefore, poses a potentially devastating threat to the future sustainability of the South African softwood industry. Strategic measures to minimise further spread are urgently needed. This review presents an overview of the impact that F. circinatum has had on South African forestry, and it considers the long-term prospects for pine forestry in the country as this relates to the presence of the pitch canker fungus.

Keywords: disease management, economic impact, host tolerance, Pinus patula, South Africa

\section{Introduction}

Pitch canker is a serious disease of pines caused by the fungus Fusarium circinatum (syn. Gibberella circinata) (Nirenberg and O'Donnell 1998, Britz et al. 2005). Fusarium circinatum was first described on infected Pinus virginiana trees in North Carolina, USA (Hepting and Roth 1946). Subsequently, the pathogen has been identified in Haiti (Berry and Hepting 1959), all of south-eastern USA down to Florida (Dwinell et al. 1985), California (McCain et al. 1987), Japan (Kobayashi and Muramoto 1989), South Africa (Viljoen et al. 1994), Spain (Dwinell et al. 1998), Mexico (Guerra-Santos 1999), Chile (Wingfield et al. 2002b), Italy (Carlucci et al. 2007) and most recently Portugal (Bragança et al. 2009).

In most parts of the world, the pitch canker pathogen is best known for the damage that it causes to established trees. Although it was known to occur on nursery seedlings elsewhere (Barnard and Blakeslee 1980, Dwinell 1999), its emergence as a major nursery pathogen in South Africa was a problem unique to this country (Viljoen et al. 1994, 1997, Bayley and Blakeway 2002, Wingfield et al. 2002a, 2008), and later also in Chile (Wingfield et al. 2002b) and Portugal (Bragança et al. 2009). In South Africa, the impact of the pathogen in nurseries has extended beyond the direct losses to nursery plants. Indeed, it is the losses that are experienced during establishment of new plantations (Mitchell et al. 2004, Crous 2005, Wingfield et al. 2008) that represents the most important manifestation of $F$. circinatum in South Africa. Within 10 years of its first detection in South Africa, F. circinatum has emerged as one of the greatest constraints to pine plantation forestry, particularly to $P$. patula, in the country.

A considerable body of international research has been conducted on the pathogen and the disease that it causes (Bethune and Hepting 1963, Cashion 1975, Dwinell et al. 1977, Dwinell and Phelps 1977, Wilkinson et al. 1977, Blakeslee and Oak 1980, Dwinell and Barrows-Broaddus 1981, Fisher et al. 1981, Storer et al. 1998, Dwinell and Fraedrich 1999, Gordon et al. 2001). In this paper we summarise some of this research, focusing on those most important aspects relating to the future sustainability of $P$. patula in South Africa. Data estimating the economic cost of $F$. circinatum on poor establishment are also presented. We further link this to the contamination rate measured in nursery studies. The importance of breeding for host tolerance in $P$. patula, and the use of hybrids and alternative species in effectively managing the disease, is discussed as the most effective long-term solution.

\section{Symptoms}

In the nursery, the primary symptoms of infection by F. circinatum include an initial tip wilting of pine seedlings. 
This is followed by the discoloration of the area beneath the growing tip (usually purpling) and, as the disease progresses, the seedlings turn brown and die (Figure $1 a-b)$. During the early stages of infection, root tips die and the roots are no longer able to take up water. Collar rot is also often observed. In the advanced stages of infection, fungal growth can occasionally be seen on the seedling stem (Figure 1c). In addition, hedge plants are particularly susceptible to infection as they are frequently wounded during shoot harvesting (Figure 1d).

On mature or established plantation trees, pitch canker displays symptoms including branch die-back, infected cones and the development of large resinous stem cankers and resin-soaked wood (Figure 2a-f) (Bethune and Hepting 1963, Dwinell and Phelps 1977, Storer et al. 1998, 1999). In South Africa, this form of the disease has been known for only a short while (Coutinho et al. 2007) and is localised to moist coastal areas in the southern Cape, similar to those in California (Gordon et al. 2001), and on marginal sites of the north-eastern Cape (RGM pers. obs.). Nevertheless, the pitch canker pathogen elicits markedly different symptoms on pines in the plantation and nursery environments, with the latter usually associated with much more rapid plant mortality (Barnard and Blakeslee 1980). To recognise these distinct forms of the disease caused by the pitch canker fungus, the nursery seedling form of the disease is referred to as $F$. circinatum infection, while the term 'pitch canker' refers exclusively to the disease on mature or established plantation trees (Wingfield et al. 1999).

The disease symptoms that develop during plant establishment are similar to those in the nursery. Mortality usually commences within the first 3 months after planting, with maximum losses between month 3 and 6 , which can persist up to 1 year (Crous 2005). In most cases, the greatest mortality is seen during the first winter season after good initial growth, indicating that the pathogen is favoured by stressful conditions (Dwinell et al. 1977, Crous 2005). However, disease symptoms can also affect recently planted seedlings during the same planting season. In such cases, survival is worse on warm wet sites while better on the moist cool sites along the Mpumalanga escarpment, where there is constant air movement (Mitchell et al. 2009).

\section{Infection and dispersal}

Infection of mature or established plantation trees by F. circinatum is reported to occur only through wounds that act as infection sites (Dwinell and Barrows-Broaddus 1981, Storer et al. 1998). These are commonly made by twig, bark and cone beetles such as species of Ips, Conophthorus, Ernobius and Pissodes nemorensis, which are also known to vector the pathogen (DeBarr and Barrows-Broadduss 1986, Storer et al. 1998, Coutinho et al. 2007). It is believed that the general absence of bark and twig-boring insects in South Africa is a possible reason that outbreaks of pitch canker on mature pine trees has remained absent for so long (Wingfield et al. 1999, 2002b). A notable exception is $P$. nemorensis, which is a well-established pest in South African pine plantations (Gebeyehu and Wingfield 2003). This insect was also found associated with the symptomatic trees examined in the Western Cape region where the first outbreak of pitch canker was detected (Coutinho et al. 2007). However, the exact role of $P$. nemorensis in the epidemiology of the disease in South Africa remains to be determined, because pitch canker could be facilitated by a number of other wounding or vectoring agents. For example, baboons have become a serious pest in stripping bark from trees (McNamara 2006). The pathogen can also gain access to the host through pruning wounds (Sakamoto and Gordon 2006). In the reported pitch canker outbreak on mature $P$. radiata in the southern Cape (Coutinho et al. 2007), stem cankers were frequently found developing around pruned branch whorls (Figure 2d) and baboon damage sites (Figure 2c). Based on these facts, it would seem that there is sufficient wounding on mature trees to facilitate the rapid spread of the disease in South Africa.

Fusarium circinatum has the ability to infect seeds both internally and externally (Storer et al. 1998, Dwinell and Fraedrich 1999), which is thought to be a major source of nursery infection (Storer et al. 1998, Dwinell and Fraedich 1999, Wingfield et al. 2008). In fact, the pathogen was probably introduced into South Africa through the importation of infected seed (Wingfield et al. 2008). This could have occurred on any one of the several introductions of $P$. patula, or of any other seed collected from Mexico, since the first introduction of $P$. patula in 1907 (Dvorak 1997). Most seed sourced from South African seed orchards, however, are still free of $F$. circinatum as these are not collected in heavily infested areas (MJW unpublished data) as seen elsewhere in the world (Storer et al. 1998). The high incidence of $F$. circinatum-associated disease in South African pine seedling nurseries is, therefore, attributed to contaminated nursery containers, irrigation water, media and plants are also a source of infection (Coutinho et al. 2007, Wingfield et al. 2008).

Once $F$. circinatum is established in the nursery, it is not fully understood how infection takes place as there is little evidence linking infection to wounding alone. Adult fungus gnats (Bradysia spp.) are known to vector plant pathogens such as Botrytis cinerea and Fusarium proliferatum in pine nurseries and their larvae feed on root material providing infection courts (James et al. 1995). As such it has been suggested that the fungus gnat ( $B$. difformis), commonly occurring in South African pine nurseries, may be associated with F. circinatum (Hurley et al. 2007). However, this hypothesis has been tested and no link between the presence of $B$. difformis and seedling infection could be established (Hurley et al. 2007). Also, it has been well documented that increasing the amount of nitrogen to pines increases infection by F. circinatum (Cashion 1975, Wilkinson et al. 1977, Fisher et al. 1981) possibly due to stimulation of succulent shoot growth (Dwinell et al. 1977, Gordon et al. 2001). If succulent tissue is predisposed to infection, this may explain why young pine seedlings in the nursery display disease symptoms without wounding.

It is commonly assumed that field infections of young plants result from planting out contaminated or infected nursery seedlings. There is strong evidence of this from previous studies. Mitchell et al. (2009) isolated $F$. circinatum from non-sterilised roots of an average of $38 \%$ of $P$. patula seedlings at the time of leaving the nursery (Figure 3 ) as well as from the roots of other species and 

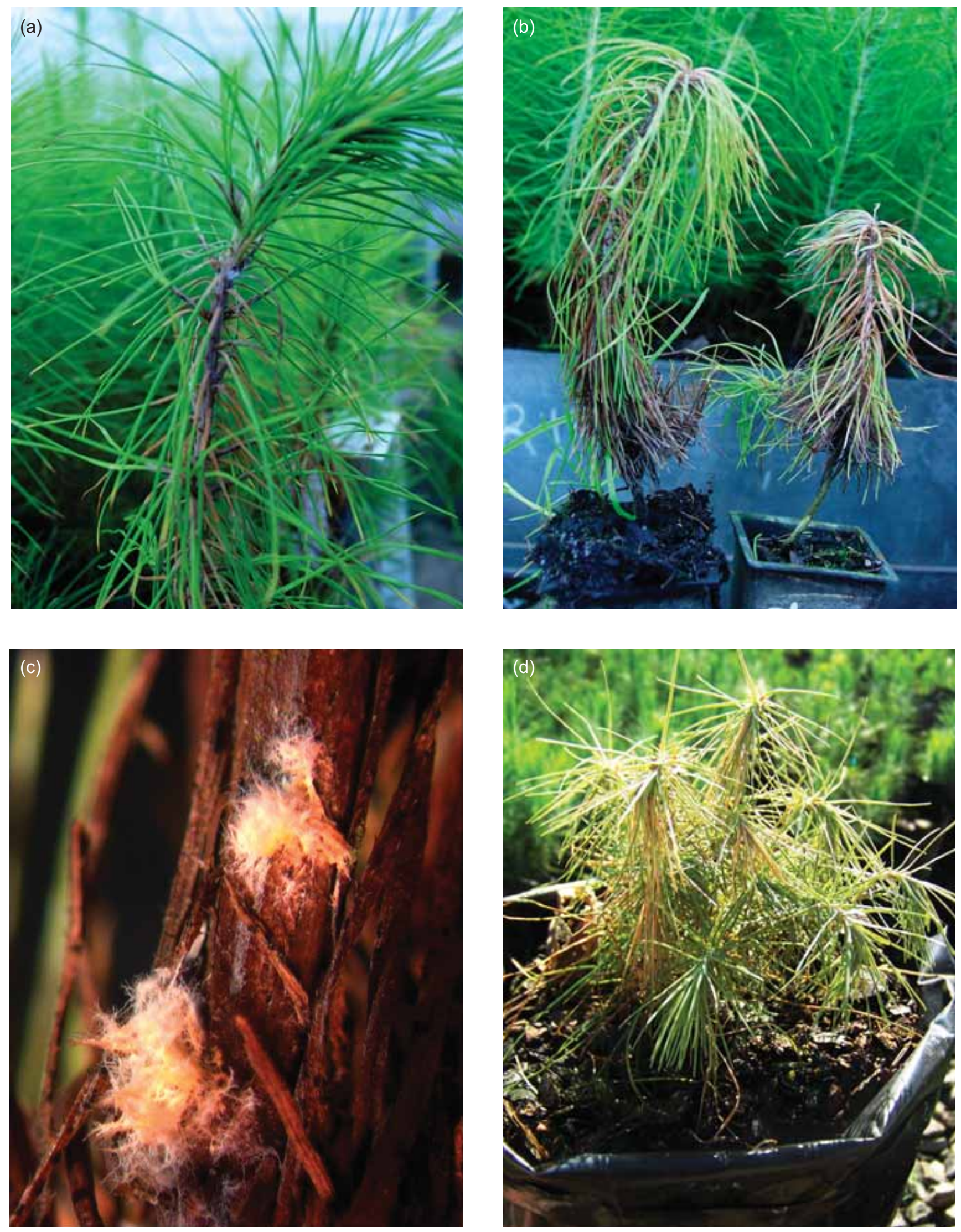

Figure 1: Nursery symptoms showing ( $a$ and b) wilting and discoloration of the seedling stem, (c) development of hyphae on a dead seedling stem, and (d) infected hedge plants 

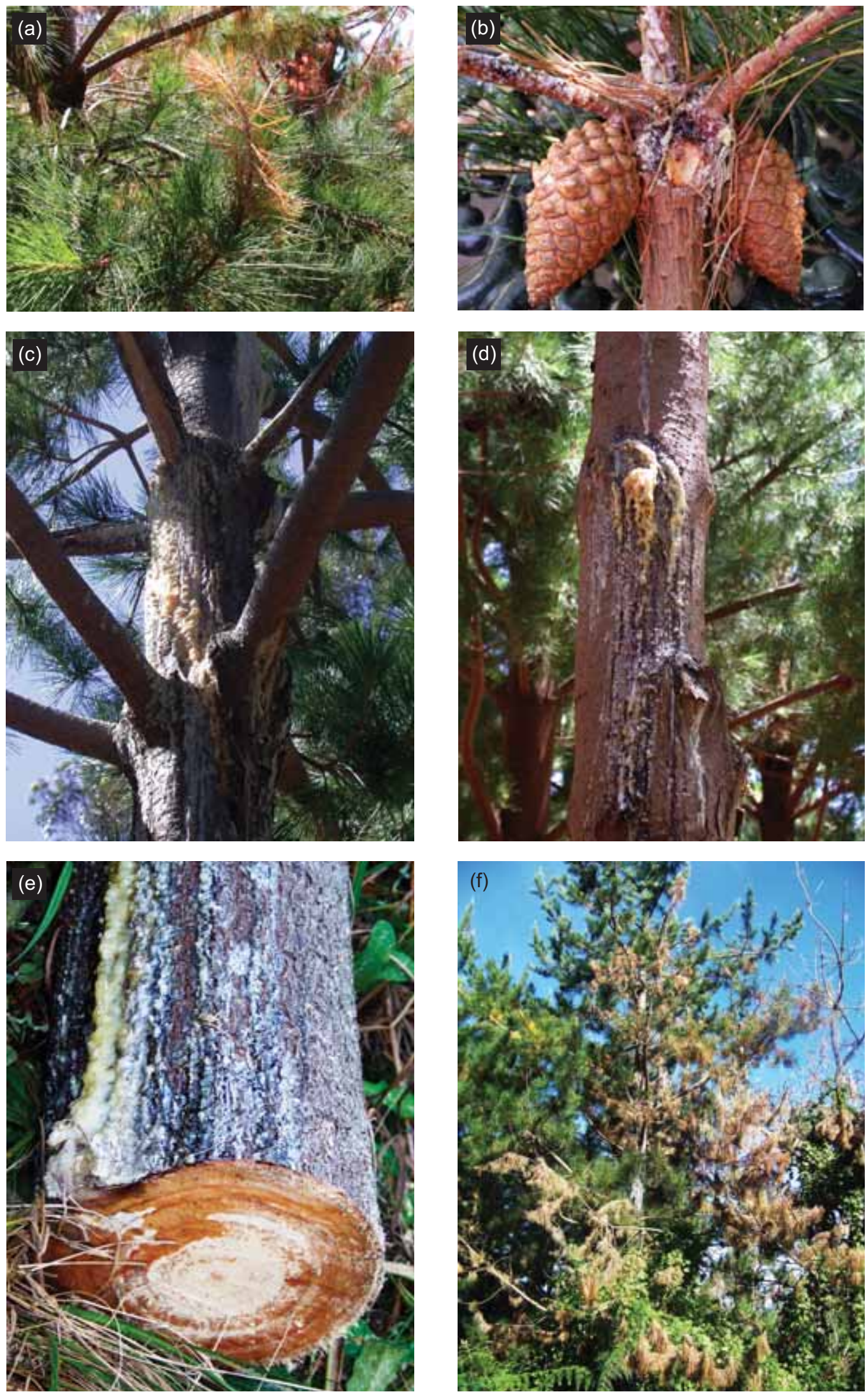

Figure 2: Pitch canker symptoms on Pinus radiata in South Africa. (a) Branch tip wilting and die-back, (b) infected cones and seed, (c) infected tree, producing copious amounts of resin, also showing branch damage by baboons, (d) infection at pruning wound sites, (e) resin-soaked internal tissue, and (f) tree death resulting from severe infection 


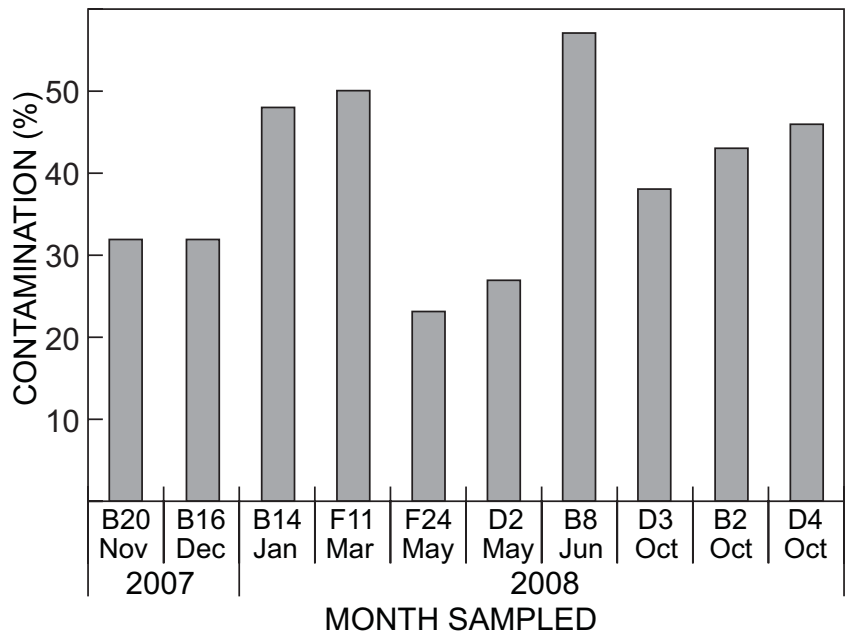

Figure 3: Percentage Pinus patula seedlings, from which Fusarium circinatum could be isolated, from seedlings displaying a healthy appearance at the time of dispatch (Mitchell et al. 2009). These results were obtained by assessing 30-50 asymptomatic seedlings on different occasions, over a one-year period from various nursery beds. The standard molecular identification method developed by Schweigkofler et al. (2004) was used to identify the presence of $F$. circinatum

hybrids, albeit in lower concentrations (Figure 4). In these studies it was found that the average contamination rate in winter is lower compared to spring or summer (Figure 3 ), with one exception from a bed sampled in June 2008 (Figure 3). This is consistent with the general experience of South African nurserymen and has been recorded elsewhere (Hammerbacher 2005). It is further relevant that the level of contamination for the different species or hybrids in the studies carried out by Mitchell et al. (2009) was consistent with the general level of tolerance of these species or hybrids in inoculation studies (Roux et al. 2007) (Figure 4).

Whether the pathogen actually gains access to the host via wounds made during planting, or whether the host is already infected upon planting is not clear. Because non-sterilised root tips were examined in the studies carried out by Mitchell et al. (2009), it may be possible that the pathogen exists as an inhabitant of the rhizosphere as described by others (Muramoto et al. 1993, Hammerbacher 2005). However, it has also been documented that plant tissue may become internally infected where $F$. circinatum can remain in a latent state before disease symptoms are expressed (Storer et al. 1998). It has been debated as to whether the presence of $F$. circinatum within healthy plant tissue can be described as an endophyte, in which case the pathogen would have no effect on tree growth until stress results in disease development. Given the fact that the pathogen is not isolated from healthy tissues of established trees, it is very unlikely that $F$. circinatum is a typical endophyte. Although it is assumed that a reduction of spore loads in the nursery will result in fewer contaminated/infected seedlings, the observed benefits of systemic fungicides, such as benomyl (Mitchell et al. 2004, Crous 2005), may support the theory that internal infection also plays a role. Understanding the principal means of nursery-

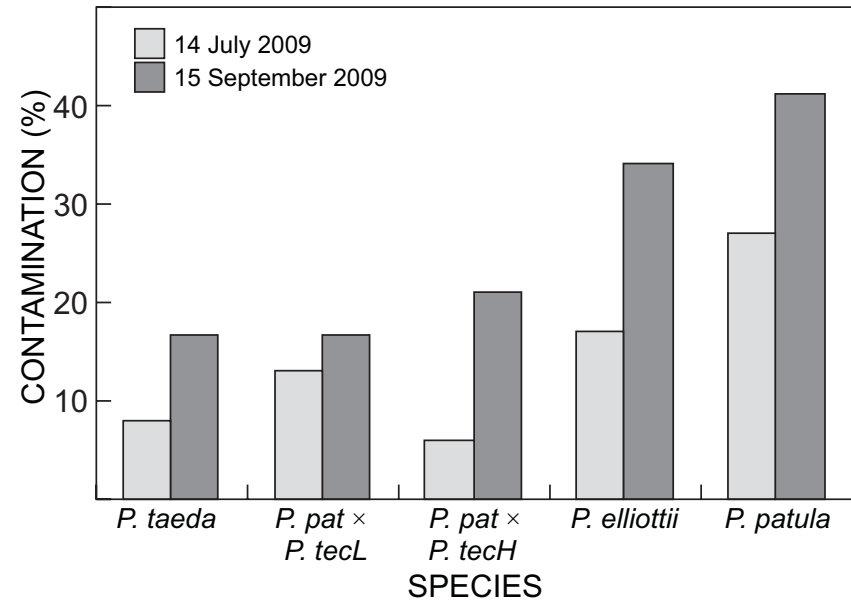

Figure 4: Percentage of asymptomatic plants, from which Fusarium circinatum was isolated from non-sterilised roots, of different pines at the time of leaving the nursery (Mitchell et al. 2009). These results were obtained by assessing 60 asymptomatic nursery plants per species/hybrid in two sampling periods. The standard molecular identification method developed by Schweigkofler et al. (2004) was used to identify the presence of $F$. circinatum

to-field transfer of this pathogen will, in the future, promote a better understanding of the epidemiology of $F$. circinatum.

\section{Economic impact}

Most information regarding the economic impact of the pitch canker fungus relates to the disease as it occurs on mature trees. Very little information has been amassed relating to the impact that $F$. circinatum has in its manifestation as a seedling pathogen in nurseries or during establishment. Although there is no doubt that much of the poor survival is related to contamination/infection by $F$. circinatum in South Africa, it is notable that other factors also play a contributing role in survival, especially with regards to $P$. patula. The effects of high temperatures, drought, insects and other pathogens have all been known to affect the survival of $P$. patula (Morris 1990, 1991, Allan and Higgs 2000, Rolando and Allan 2004). An increase in herbicide damage to young $P$. patula plantings has also been noted (RGM unpublished data). These factors may make it difficult to quantify the impact of $F$. circinatum on survival.

To better understand the cost to the South African industry, where it remains predominantly a nursery and re-establishment problem, losses due to $F$. circinatum have been measured by rouging dying plants in the nursery and carrying out field survival counts. Rouging dying plants usually amounts to less than $1 \%$ of the crop (RGM unpublished data). However, field losses are significant. In a comprehensive study, covering 16 different sites, Crous (2005) reported that $F$. circinatum was isolated from $42 \%$ of all dying plants removed from the field in the months following establishment. The study was conducted over two planting seasons between 2003 and 2005. His data showed that mean survival was $36-53 \%$ after the first year. Based on these data, and the fact that survival of less than $30 \%$ is often recorded, it can be assumed that at least half of all measured mortality 
is due to F. circinatum. Thus, for every 100 plants planted, 25 would probably die because they were either infected or contaminated by $F$. circinatum in the nursery. The remaining 25 would die from other causes mentioned.

Using the information generated by Crous (2005), and the current establishment costs (pitting, planting and blanking), Mitchell et al. (2009) calculated this loss to be R602 ha-1 for the saw timber industry, and R896 ha-1 for the pulpwood industry (Table 1). Extrapolated over South Africa, where approximately 15000 ha are planted annually to $P$. patula (DAFF 2008), the impact of $F$. circinatum on tree survival costs the local forest industry in excess of R11 million per year (Mitchell et al. 2009). Morris (2010) recently estimated this to be $\mathrm{R} 12$ million, when $P$. radiata is included together with $P$. patula.

At this stage, insufficient data exist to quantify the economic loss due to pitch canker outbreaks in the southern and south-eastern Cape on $P$. radiata and $P$. greggii. Based on field infections elsewhere in the world, the most significant impact of pitch canker occurs because of the loss in volume growth. Reduction in growth of $P$. elliottii infected stands has been reported to be $15-72 \%$ depending on the severity of infection (Bethume and Hepting 1963, Dwinell and Phelps 1977, Arvanitas et al. 1984). In more tolerant species such as $P$. elliottii and $P$. taeda, not all infected trees die (Dwinell and Phelps 1977). However, in severe cases, mortality in $P$. elliottii stands can reach levels of $25 \%$ with up to $98 \%$ of all trees showing some signs of infection (Blakeslee and Oak 1980). Gordon et al. (2001) have also reported a $98 \%$ infection rate in $P$. radiata where, owing to the susceptibility of the species, more trees would be expected to die. If the disease manifests itself as a serious problem in plantations in South Africa, losses are likely to be of a similar magnitude in the infected areas. However, as seen from examples in California (Gordon et al. 2001) and South Africa (Coutinho et al. 2007), infection is greatest in coastal areas. It also appears from the outbreak on $P$. greggii in the north-eastern Cape that dry marginal sites are also at risk (RGM pers. obs.). Based on these experiences, it could be speculated that the areas on the Mpumalanga escarpment may be less threatened.

\section{Disease management}

\section{Field}

One of the main strategies for preventing the occurrence or spread of pitch canker in established pine plantations is to limit wounding. Although this may in part be possible through effective control of insect and baboon damage, appropriate silvicultural practices are also important. For example, it has been shown that pruning wounds increase the risk of infection by $F$. circinatum (Sakamoto and Gordon 2006), which may be particularly important in saw timber stands. Care should be taken not to damage standing trees by harvesting equipment and tree removal when thinning compartments. Although pitch canker has not become an established pathogen of seed orchard trees in South Africa, cones should be clipped and not sheared from the branch whorls when harvesting (Dwinell and Barrows-Broaddus 1981, DeBarr and Barrows-Broadduss 1986).

There are indications that water stress predisposes trees to infection (Dwinell et al. 1977) and thus, the stress associated with the high stocking density of pulpwood stands, has been observed (Dwinell and Phelps 1977, Blakeslee et al. 1993, Barnard and Blakeslee 2006). This can, therefore, be limited by avoiding the planting of susceptible species such as $P$. patula on sites prone to drought, and carrying out timely thinnings (Berry and Hepting 1969, Blakeslee and Rockwood 1999). It has also frequently been reported that pitch canker outbreaks are often associated with the application of nitrogen (Cashion 1975, Wilkinson et al. 1977, Barnard and Blakeslee 2006). The benefits of improving growth through mid-rotation fertiliser application are being considered and practised in some areas of South Africa (Carlson et al. 2008). If the fertiliser applied contains higher amounts of nitrogen, relative to the other macronutrients in the fertiliser, this practice may be counterproductive in the cases where pitch canker has become established or where the risk of infection is high.

\section{Nursery}

Controlling $F$. circinatum in pine nurseries remains the most important means of reducing field mortality at establishment. Some nurseries report that the control of $F$. circinatum is particularly difficult, while others report better control. This may be because nurserymen do not wish to disclose the extent of the problem, but there may also be some scientific evidence for this observation. Previous studies on $F$. oxysporum have indicated large variation in virulence for different isolates on nursery seedlings (James and Gilligan 1984), and also differences in virulence of isolates collected from different nurseries (James et al. 1999). Similarly, the same has been shown for different isolates of $F$. circinatum (Dwinell 1978, Gordon et al. 2001). This suggests that isolates, unique to specific nurseries in South Africa, may have resulted in the observed differences in the severity of outbreaks between other nurseries in South Africa. Nevertheless, nurserymen have now come to accept that

Table 1: Approximate cost of Fusarium circinatum-related mortality per hectare based on a planting density of 1111 or 1667 stems ha-1 (Mitchell et al. 2009)

\begin{tabular}{|c|c|c|c|c|c|}
\hline \multirow[t]{2}{*}{ Activity } & \multicolumn{2}{|c|}{ Establishment cost (rands) } & \multicolumn{2}{|c|}{$\begin{array}{c}\text { Cost due to } F \text {. circinatum } \\
\text { (25\% of establishment costs) (rands) }\end{array}$} & \multirow{2}{*}{$\begin{array}{c}\text { Mean cost } \\
\text { (rands) }\end{array}$} \\
\hline & 1111 stems ha $^{-1}$ & 1667 stems ha $^{-1}$ & 1111 stems ha $^{-1}$ & 1667 stems ha $^{-1}$ & \\
\hline$\overline{\text { Pitting }}$ & 633 & 950 & 158.25 & 237.50 & 187.88 \\
\hline Planting (including plants) & 1143 & 1715 & 285.75 & 428.75 & 357.25 \\
\hline Blanking (including plants) & 611 & 917 & 157.75 & 229.25 & 193.50 \\
\hline Total cost per hectare & 2388 & 3582 & 601.75 & 895.50 & 738.63 \\
\hline
\end{tabular}


once $F$. circinatum is present in their nurseries, eradication is almost impossible. At best, the disease can be managed through an integrated management approach. Maintaining effective nursery hygiene is practiced by nurserymen and nurseries are audited annually by the Seedling Growers Association of South Africa to ensure high standards. Nurserymen are required to regularly remove dying seedlings and dispose of them by removal from the site or burning (PFWG 2004).

Reported control of Fusarium on seed includes soaking seeds in diluted solutions of ethanol, sodium hypochlorite, hydrogen peroxide, in hot water $\left(90 \mathrm{~s}\right.$ at $55.5^{\circ} \mathrm{C}$ ) and imbibing seeds with a biological control agent (Pseudomonas chlororaphis) before cold stratification (Dumroese et al. 1988, Hoefnagels and Linderman 1999). The fungicides benomyl and thiram have also been used to treat seed (Dwinell 1999). Most South African nurseries sterilise their trays by treating with steam $\left(70-80^{\circ} \mathrm{C}\right)$ for 60-90 min in sealed containers (M Kruger pers. comm., Top Crop nursery, 2008). Some authors report that effective control of Fusarium from polystyrene trays can be achieved by using a combination of a hot water $\left(90 \mathrm{~s}\right.$ at $\left.80^{\circ} \mathrm{C}\right)$ and copper treatment (James and Wollen 1989, Dumroese et al. 2002). However, the most effective method to control $F$. circinatum in polystyrene trays is to make use of only new trays when sowing $P$. patula.

Ensuring that irrigation water is free from contamination is crucial to control $F$. circinatum in nurseries. Most South African nurserymen have used calcium hypochlorite (chlorine) to sterilise irrigation water before use. This can be achieved either by injecting chlorine gas into the irrigation water or by adding chlorine tablets or granules to the water. Although the recommended rate of $0.5-1 \mu \mathrm{g} 1^{-1}$ provides good control (Newman 2004), up to $10 \mu \mathrm{g} 1^{-1}$ has been used both to sterilise the water and to disinfect the plants and growing medium before being allowed to dissipate from the water as a gas (M Kruger pers. comm., Top Crop nursery, 2008). Effective control of various nurseryassociated pathogens has also been achieved by treating contaminated water with hydrogen peroxide and ozone (Newman 2004). Sterilants, such as Sporekill ${ }^{\circledR}$, Prasin ${ }^{\circledR}$ and sodium hypochlorite (household bleach), have also shown to be effective in controlling Fusarium oxysporum spores in laboratory studies (Nel et al. 2007).

Once established in a nursery, fungicides are commonly applied to reduce infection by F. circinatum. In South Africa, however, their application is increasingly being restricted to the few fungicides that pose little threat to the environment and human health (FSC 2002). The most widely applied fungicides in South African nurseries to control $F$. circinatum contain the active ingredient benomyl (from the benzimidazole group). The strong control that benomyl has on $F$. circinatum has been shown in laboratory studies (Dwinell and Barrows-Broaddus 1981, Mitchell 2005), in nursery trials (Mitchell et al. 2004) and on the post-planting survival of $P$. patula after applications at planting (Crous 2005). However, the use of benomyl has now been banned by the Forest Stewardship Council (FSC 2002). Other fungicides containing tebuconazole, prochloraz-manganese, and propiconazole have also provided good control of F. circinatum in laboratory in vitro studies (Mitchell 2005), although their application has not been tested in vivo. Few fungicides may, therefore, be suitable for controlling $F$. circinatum and the majority still remain largely untested. In addition to the environmental dangers associated with fungicide use, there is strong evidence that pathogens build up resistance to fungicides over time, which is especially true of fungicides containing benomyl (Staub and Sozzi 1984). Although fungicides are still being applied in an attempt to control $F$. circinatum in South Africa, elsewhere in the world the use of fungicides is reported as ineffective (EMPPO 2005, Barnard and Blakeslee 2006).

Apart from the traditional application of fungicides, effective control of various Fusarium pathogens by using biological organisms has been extensively documented (Sylvia and Sinclair 1983, Sneh et al. 1985, Hoefnagels and Linderman 1999). The most commonly reported biocontrol agents are species of Trichoderma (Bell et al. 1982, Ordentlich et al. 1991), of which T. harzianum is reported to be especially effective (de la Cruze et. al. 1995, Bacon et al. 2001). Some studies indicate strong inverse relationships between the amount of naturally occurring Trichoderma and pathogenic Fusarium species found on Douglas-fir seed (James et al. 1987). Although biocontrol agents have in many cases been shown to control other species of Fusarium, control appears to be less effective against $F$. circinatum. Tests carried out in vitro showed very effective control of $F$. circinatum using a single $T$. harzianum strain (Mitchell 2005) and, applied in the nursery, T. harzianum is associated with improved survival and growth of the nursery plants (Mitchell et al. 2004). However, after receiving applications of $T$. harzianum in the nursery, no improvement in field survival could be seen and, when applied in the field, benefits were short-lived (Mitchell et al. 2004). Therefore, although there may be some benefits to applying biocontrol agents, they need to be applied within an integrated pest management approach to obtain satisfactory results (Axelrood 1990).

\section{Long-term management strategies}

In order to reduce the risk of large-scale plantation losses to pitch canker in the long term, several breeding strategies can be employed. First, the greater tolerance of some species over others (Viljoen et al. 1995, Hodge and Dvorak 2000) suggests that more-tolerant species could be planted as substitutes, where possible. Secondly, the susceptible species can be hybridised with more-tolerant species in order to impart tolerance to the progeny (Roux et al. 2007). Thirdly, the use of more-tolerant families or clones within a generally accepted susceptible species has shown improved tolerance (Rockwood et al. 1988). These can be selected and deployed, or used to control-pollinate other individuals of the same species in breeding programs.

\section{Strategy 1: alternative species}

Because of the variation between pine species in their tolerance to various diseases, the simplest genetic strategy to reduce risk in plantations of non-native trees is to plant a number of species and not rely on large-scale plantings of a few or a single species (Wingfield 1999, Wingfield et al. 2001, 2002a). For South Africa, this is particularly true 
if the main species planted is known to be susceptible to $F$. circinatum such as is the case with $P$. patula, in the summer rainfall regions, and $P$. radiata in the winter rainfall regions. Greenhouse studies and field observations have shown significant variation in host susceptibility to $F$. circinatum at the species, provenance, family and clonal level (Dwinell et al. 1977, Dwinell and Barrows-Broaddus 1982, BarrowsBroaddus and Dwinell 1984, Hodge and Dvorak 2000, 2007, Roux et al. 2007). The first comprehensive study conducted on a large number of species from all subsections of Pinus was published by Hodge and Dvorak (2000). Using the pine taxonomic classification system of Price et al. (1998), $P$. radiata in the subsection Attenuatae was the most susceptible of all the species tested. There was great variability in susceptibility within subsection Oocarpae, Oocarpa group. Pinus patula and $P$. greggii from this group were the most susceptible but not as much so as $P$. radiata. Pinus tecunumanii in the Oocarpa group from high-elevation regions of Mexico and Central America was moderately susceptible, and $P$. oocarpa, $P$. pringlei, $P$. jaliscana and $P$. tecunumanii from low-elevation areas showed high levels of tolerance (Hodge and Dvorak 2000). In the Ponderosae subsection, Pseudostrobus group, $P$. maximinoi was more tolerant than $P$. pseudostrobus. Species from subsection Australes were moderately susceptible with $P$. elliottii showing the least tolerance, $P$. taeda slightly more, and all varieties of $P$. caribaea showing the highest level of tolerance (Hodge and Dvorak 2000).

Because of the high level of tolerance of South Africa's other main planted pines, $P$. elliottii and $P$. taeda, companies have increased plantings of these significantly in the last 10 years in an effort to improve field survival. This is despite the fact that both the wood quality, and often the growth, of $P$. elliottii and $P$. taeda is inferior to that of $P$. patula (Kietzka 1988, Malan 2003). It is also unclear whether these losses in growth and wood quality are not costing the industry more than the cost of increased blanking operations when planting $P$. patula. There are, however, a number of alternative species that show good growth compared to $P$. patula, as well as tolerance to $F$. circinatum. Two such species are $P$. tecunumanii and $P$. maximinoi if planted on the warmer sites of South Africa (Kietzka 1988, Malan 1994, Galpare et al. 2001). Furthermore, studies have shown that these species have outstanding wood properties (Malan 1994, 2006). Other pines showing acceptable tolerance to $F$. circinatum and promising growth potential are $P$. teocote and $P$. pseudostrobus, suited to the cooler regions of the country, and $P$. pringlei, suited to the subtemperate regions of South Africa (Darrow and Coetzee 1983, Coetzee 1985, Malan 2003). The development of $F$. circinatum in South Africa has no doubt called for renewed interest in alternative species and, with advancements in tree breeding, will mean a likely increase in their deployment.

\section{Strategy 2: hybridisation}

A contemporary approach to dealing with diseases is to develop hybrids between resistant and susceptible plants. A good example of this already established technique can be seen in the Eucalyptus genus (Bayley and Blakeway 2002). Early plantings of pure E. grandis in the subtropical regions of South Africa were severely hampered by stem cankers caused by Chrysoporthe austroafricana and Kirramyces zuluense (Bayley and Blakeway 2002). By hybridising $E$. grandis with $E$. urophylla and E. camaldulensis, and selecting tolerant clones from these hybrids, significant improvement in tolerance was achieved (Wingfield 1999, van Zyl and Wingfield 1999, Wingfield et al. 2001, Bayley and Blakeway 2002, van Heerden et al. 2005). Added benefits of these hybrids were improved wood quality and drought tolerance (Malan 1993). These examples indicate that a similar approach can be used to improve the tolerance of susceptible pines to F. circinatum. Indeed, some studies have already shown this. Hybrids between $P$. patula and more-tolerant partners such as $P$. tecunumanii and $P$. oocarpa are significantly more tolerant to F. circinatum on three-year-old trees (Roux et al. 2007).

The commercial deployment of pine hybrids in South Africa has been predominantly to $P$. elliottii $\times P$. caribaea (Bayley and Blakeway 2002). However, in recent years, interest in $P$. patula hybrids, such as $P$. patula $\times P$. tecunumanii and $P$. patula $\times P$. oocarpa, has seen a drastic increase in an effort to overcome the survival issues in $P$. patula. Furthermore, these hybrids are performing exceptionally well in early field trials. This is especially true of $P$. patula $\times P$. tecunumanii ( $\mathrm{Nel}$ et al. 2006). Assuming that companies have access to pollen sources of species such as $P$. tecunumanii and $P$. oocarpa, hybrids can be made within a three-year period and can be easily mass-propagated as cuttings. For companies that may not have access to selections from these hybrid partners, or the capacity to produce large quantities of control-pollinated hybrid seed, alternative species may be required.

\section{Strategy 3: breeding and selection}

Many authors report that tolerance of individual clones to $F$. circinatum is under strong genetic control and that improvement in tolerance is best done through selecting and breeding with more-tolerant clones (Rockwood et al. 1988, Gordon et al. 1999, Storer et al. 1999, 2001). Even in susceptible species, such as $P$. radiata, individuals in natural stands show appreciable tolerance to $F$. circinatum (Storer et al. 1999, Gordon et al. 2001). Carrying out artificial inoculation studies to identify host tolerance is not easily done on mature trees. The ability of pathogens to elicit disease symptoms is largely dependent on the environmental conditions during infection (Dwinell and BarrowsBroaddus 1981, 1982, Wingfield et al. 2008). In addition, infection studies in the field increase the risk of contaminating surrounding trees not intended for experimentation (Storer et al. 1999). A popular, and more practical, method commonly used is to artificially inoculate large numbers of seedlings in a controlled environment such as a greenhouse (Gerhold 1970, Hodge and Dvorak 2000, 2007). In this way, many treatments can be screened to determine their tolerance to the pathogen with which they are being challenged and without confounding environmental effects. Consequently, tree breeders attempting to identify resistant families and clones to $F$. circinatum began employing this technique in the last decade. The Bent Creek Experimental Station in Ashville, North Carolina, as well as the Forestry and Agricultural Biotechnological Institute (FABI) at the University of Pretoria, are used to screen several hundred 
pine families a year to assist breeders in identifying diseasetolerant species, families and clones.

Although there are numerous examples showing the value of greenhouse inoculation studies (Barrows-Broaddus and Dwinell 1984, Blakeslee and Rockwood 1999, Gordon et al. 1999, Vogler and Kinloch 1999), there is some concern that greenhouse screening studies in South Africa do not provide sufficiently meaningful results when screening the progeny of $P$. patula seed orchard clones against $F$. circinatum. Understanding the factors that may confound the results of greenhouse inoculation studies will help to improve techniques and the value of these studies. A problem associated with greenhouse screening lies in the fact that young plants are apparently more susceptible to infection by $F$. circinatum than mature trees in the field. Furthermore, infecting trees with spore concentrations higher than those that might occur naturally can confound the results. For example, inoculating healthy 2 -month-old $P$. patula seedlings with a spore drench will kill all seedlings within 4 weeks (Viljoen et al. 1994). However, when inoculating 4-year-old $P$. patula trees, signs of recovery can be seen 10 months from the inoculation date (Viljoen et al. 1995). Similarly, $P$. patula, well-known to be more tolerant than $P$. radiata (Hodge and Dvorak 2000, 2007, Roux et al. 2007), showed no difference in susceptibility compared with $P$. radiata when mycelial plugs from agar plates were placed directly onto wounded 1-year-old seedling stems (Viljoen et al. 1995). In another experiment, $P$. radiata seedling survival was $2.1 \%$ when 'low' levels of inoculum (50 000 spores $\mathrm{ml}^{-1}$ ) and $0.3 \%$ when 'high' levels (100 000 spores $\mathrm{ml}^{-1}$ ) were applied to topped seedlings, resulting in no measured variation in the tolerance of $P$. radiata to $F$. circinatum with either concentration (Hodge and Dvorak 2000). On the other hand, when studying the effect of $F$. circinatum on mature $P$. radiata, levels of as little as 25 spores per infection site (a $1.6 \mathrm{~mm}$ diameter wound on the branch) elicited sufficient disease symptoms to differentiate family tolerance (Storer et al. 1999). These examples suggest that applying sufficient quantities of spores to discriminate between family tolerances as seedlings, without killing all treatments in greenhouse studies, is an important consideration.

The effects of increasing maturation on reduced susceptibility to $F$. circinatum can be seen even at a young age where cuttings are often more tolerant to infection than seedlings of the same families (RGM unpublished data). This has also been recorded for other diseases such as red band needle blight caused by Dothistroma septosporum (Ades and Simpson 1990), western gall rust (Endocronartium harknessii) (Zagory and Libby 1985, Power et al. 1994) and fusiform rust (Cronartium quercuum) (Frampton et al. 2000). This suggests that the comparison of different treatments, where some may be represented as seedlings and others as cuttings in the same inoculation study, will confound results.

Although the validity of greenhouse screenings to determine family tolerance to $F$. circinatum has been questioned in South Africa, there are examples indicating that greenhouse screening tests are useful. Studies on $P$. virginiana produced reasonable correlations in two consecutive greenhouse inoculation studies with $F$. circinatum with the observed susceptibility of the parent clones in a seed orchard (0.68 and 0.86). Although the correlation was weak when compared to a limited number of the families in a progeny test planted from the same orchard (Barrows-Broaddus and Dwinell 1984), the most tolerant family in the field study was related to the most tolerant clone in the orchard. In other studies, a susceptible $P$. elliottii clone is used as a standard control check in greenhouse screening studies where it consistently ranks as highly susceptible (Hodge and Dvorak 2000, 2007). This indicates that, although the juvenile (greenhouse)-mature (field) correlation may be weaker than hoped for, the relationship is sufficiently strong to be useful when identifying families at the extreme range of infection (Vogler and Kinloch 1999).

To overcome the problems associated with greenhouse inoculation studies, a backwards selection approach using mature trees may be more effective than forward selection. Rockwood et al. (1988) reported very strong heritabilities from five field tests that averaged 0.67 in artificially and naturally infected tests. From this observation they suggest that, for those incidences where pitch canker is well established in field plantings, seed stands of more tolerant individuals can be achieved by rouging infested stands down to the most tolerant trees. Based on the encouraging results achieved from this and other (Storer et al. 1999, 2001) field studies, South African tree breeders could consider inoculating plus trees in progeny trials before establishing new seed orchards with these. This should provide for more reliable and meaningful results. Trees should be inoculated once seed and grafting material have been harvested from the selections to ensure their posterity.

\section{The future of Pinus patula in South Africa}

The susceptibility of $P$. patula to $F$. circinatum will severely impact the future deployment of the species in this country. Although the problem remains confined at this stage to re-establishment failure, there is the likelihood that $F$. circinatum could result in pitch canker on mature $P$. patula and other pine trees. This highlights the urgent need to reconsider the deployment of $P$. patula, not only to limit further spread in South Africa, but also to prevent the spread of the fungus into the rest of southern Africa.

The current lack of effective control in nurseries and in young field plantings increases the risk and cost to propagate this species. Chemicals, biocontrol agents and even increased nursery hygiene appear to have limited effect. Selection and breeding more-tolerant families appears to be the only feasible solution to the problem if breeders wish to continue with the deployment of $P$. patula. In order to improve the tolerance of the current breeding populations, greenhouse screening studies are the most simple and rapid technique available to breeders. Such studies should effectively distinguish those families that are highly tolerant from those that are highly susceptible in field infections (Vogler and Kinloch 1999). Owing to the general lack of tolerance of $P$. patula to $F$. circinatum, especially at the seedling stage, it may be too ambitious to expect that, by deploying the more-tolerant families from greenhouse studies, the field survival problem will be resolved. Although there may be some improvement in field survival the importance of greenhouse screening trials is to identify families which, as mature trees, will be more 
tolerant to pitch canker. A drawback of this method is that seed quantities are drastically reduced as the more-tolerant clones are selectively harvested in orchards. Immediate deployment of these families, therefore, may have to rely on vegetative propagation (Gordon et al. 2001). The best long-term solution would be to establish new clonal seed orchards of selected clones.

Deployment of either $P$. patula hybrids or the replacement with alternative species will mean a change in the future distribution of $P$. patula. Hybrids with subtropical species such as $P$. tecunumanii and $P$. oocarpa will extend the range of $P$. patula to include lower-altitude warmer sites. The susceptibility of $P$. patula to Diplodia pinea on low-altitude sites, where hail is a common occurrence (Smith et al. 2002), is still to be determined in the hybrids. Planting of the hybrids may be limited to sites with light or no frost, leaving $P$. patula as the primary choice for very high-altitude sites. The frost susceptibility of hybrids between $P$. patula and subtropical species may be overcome by breeding for cold tolerance. Significant effort has gone into breeding $P$. patula with some breeding programs including selections from third-generation progeny tests in new seed orchards (Dvorak 1997). Unless the tolerance of these high-yielding selections is not improved by control-pollination with known tolerant families, or through hybridisation with tolerant species, their deployment may never be realised. Breeders will in the future have to increase efforts into breeding alternatives and $P$. patula hybrids to overcome the susceptibility of this species. These changes, and the inevitable reduction of plantings of pure $P$. patula, will raise new challenges and opportunities for the South African forest industry.

Acknowledgements - We thank members of the Tree Protection Co-operative Programme, the THRIP initiative of the Department of Trade and Industry, South Africa, and Komatiland Forests for financial support. We are also grateful to many colleagues linked to the South African forestry industry for useful discussions and ideas that have been captured in this overview.

\section{References}

Ades PK, Simpson JA. 1990. Clonal selection for resistance to Dothistroma needle blight in Pinus radiata. New Forests 4: 27-35.

Allan R, Higgs G. 2000. Methods of improving the survival of Pinus patula planted into harvest residues. Southern African Forestry Journal 189: 47-51.

Arvanitas LG, Godbee JF Jr, Porta I. 1984. Pitch canker impact on growth: a case study in slash pine plantations. Southern Journal of Applied Forestry 8: 43-47.

Axelrood PE. 1990. Biocontrol of plant pathogens: principles and strategies. Paper presented at the First Meeting of the IUFRO Working Party S2.07-09, Diseases and Insects in Forest Nurseries, 22-30 August 1990, Victoria, British Columbia, Canada.

Bacon CW, Yates IE, Hinton DM, Filmore M. 2001. Biological control of Fusarium moniliforme in maize. Environmental Health Perspectives 109: 325-332.

Barnard EL, Blakeslee GM. 1980. Pitch canker on slash pine seedlings: a new disease in forest tree nurseries. Plant Disease 64: 695-696.

Barnard EL, Blakeslee GM. 2006. Pitch canker of southern pines. Plant Pathology Circular no. 302. Gainesville: Florida Department of Agriculture and Consumer Services, Division of Plant Industry.

Barrows-Broaddus J, Dwinell LD. 1984. Variation in susceptibility to the pitch canker fungus among half-sib and full-sib families of Virginia pine. Phytopathology 74: 438-444.

Bayley AD, Blakeway F. 2002. Deployment strategies to maximise value recovery from tree improvement: the experience of two South African companies. Southern African Forestry Journal 195: 11-22.

Bell DK, Wells D, Markham CR. 1982. In vitro antagonism of Trichoderma species against six fungal plant pathogens. Phytophatology 72: 379-382.

Berry CR, Hepting GH. 1959. Pitch canker of southern pines. Forest Pest Leaflet no. 35. Washington, DC: US Department of Agriculture, Forest Service.

Bethune JE, Hepting GH. 1963. Pitch canker damage to south Florida slash pine. Journal of Forestry 61: 517-522.

Blakeslee GM, Allen JE, Lante WE. 1993. Post-thinning disease and growth responses of pitch canker infected slash pine in the flatwoods of Florida. In: Brissette JC (ed.), Proceedings of the Seventh Biennial Southern Silvicultural Research Conference, Mobile, Alabama, 17-19 November 1992. New Orleans: US Department of Agriculture, Forest Service, Southern Forest Experiment Station. pp 533-539.

Blakeslee GM, Oak SW. 1980. Significant mortality associated with pitch canker infection of slash pine in Florida. Plant Disease 63: 1023-1025

Blakeslee GM, Rockwood D. 1999. Variation in resistance to pitch canker in slash and loblolly pines. In: Devey ME, Matheson AC, Gordon TR (eds), Current and Potential Impacts of the Pitch Canker in Radiata Pine: Proceedings of the IMPACT Monterey Workshop, Monterey, California, 30 November to 3 December 1998. Canberra: CSIRO. pp 70-75.

Bragança H, Diogo E, Moniz F, Amaro P. 2009. First report of pitch canker on pines caused by Fusarium circinatum in Portugal Plant Disease 93: 1079

Britz $\mathrm{H}$, Coutinho TA, Wingfield BD, Marasas WFO, Wingfield MJ. 2005. Diversity and differentiation in two populations of Gibberella circinata in South Africa. Plant Pathology 54: 46-52.

Carlson CA, Fox TR, Allen HL, Albaugh TJ. 2008. Modelling mid-rotation fertilizer responses using the age-shift approach Forest Ecology and Management 256: 256-262.

Carlucci A, Colatruglio L, Frisullo. 2007. First report of pitch canker caused by Fusarium circinatum on Pinus halepensis and $P$. pinea in Apulia (southern Italy). Plant Disease 91: 1683.

Cashion NL. 1975. Effects of nutrition on susceptibility of slash and loblolly pines to Fusarium moniliforme var. subglutinans and studies on the fungus in vitro. MSc thesis, University of Georgia, USA.

Coetzee H. 1985. Provenance research on Mexican pines. Southern African Forestry Journal 135: 68-73.

Coutinho TA, Steenkamp ET, Mongwaketsi K, Wilmot M, Wingfield MJ. 2007. First outbreak of pitch canker in a South African pine plantation. Australasian Plant Pathology 36: 256-261.

Crous JW. 2005. Post establishment survival of Pinus patula in Mpumalanga, one year after planting. Southern African Forestry Journal 205: 3-8.

DAFF (Department of Agriculture, Forestry and Fisheries). 2008. Report on commercial timber resources and primary round wood processing in South Africa 2007/2008. Pretoria: Directorate: Forestry Technical and Information Services.

Darrow K, Coetzee H. 1983. Potentially valuable Mexican pines for the summer rainfall region of southern Africa. Southern African Forestry Journal 124: 23-35.

de la Cruze J, Pintor-Toro JA, Benítez T, Llobell A. 1995 Purification and characterization of an endo- $\beta-1,6$-glucanase from Trichoderma harzianum that is related to its mycoparasitism. Journal of Bacteriology 177: 1864-1871.

DeBarr GL, Barrows-Broaddus J. 1986. Cone and seed pest problems in the United States. Paper presented at the North American Forestry Congress, 21 October 1986, Athens, Georgia. 
Dumroese RK, James RL, Wenny DL. 2002. Hot water and copper coatings in reused containers decrease inoculum of Fusarium and Cylindrocarpon and increase Douglas-fir seedling growth. Horticultural Science 37: 943-947.

Dumroese RK, James RL, Wenny DL, Gilligan CJ. 1988. Douglasfir seed treatments: effects on seed germination and seedborne organisms. In: Landis TD (tech. coord.), Proceedings: Combined Meeting of the Western Forest Nursery Council, Intermountain Nursery Association and Forest Nursery Association of British Columbia, 8-11 August 1988, Vernon, British Columbia. Fort Collins: US Department of Agriculture, Forest Service, Rocky Mountain Forest and Range Experiment Station. pp 155-160.

Dvorak W. 1997. Improvement and breeding of Pinus patula. In: White T, Huber D, Powell G (eds), Proceedings of the 24th Biennial Southern Forest Tree Improvement Conference, Orlando, Florida, 9-12 June 1997. Orlando: Southern Tree Improvement Committee. pp 53-68.

Dwinell LD. 1978. Susceptibility of southern pines to infection by Fusarium moniliforme var. subglutinans. Plant Disease Reporter 62: 108-111.

Dwinell DL. 1999. Contamination of Pinus radiata seeds in California by Fusarium circinatum. Paper presented at the 1999 Annual International Research Conference on Methyl Bromide Alternatives and Emissions Reductions, 1-4 November 1999, San Diego.

Dwinell LD, Adams D, Guerra-Santos JJ, Aquirre JRM. 1998. Pitch canker disease of Pinus radiata. Paper presented at the 7 th International Congress of Plant Pathology, 9-16 August 1998, Edinburgh.

Dwinell LD, Barrows-Broaddus JB. 1981. Pitch canker in seed orchards. In: Proceedings of the Sixteenth Southern Forest Tree Improvement Conference, 27-28 May 1981, Blacksburg, Virginia. pp 234-240.

Dwinell LD, Barrows-Broaddus JB. 1982. Variability of the host and pathogen in the pitch canker complex. In: Heybrook HM, Stephan $\mathrm{BR}$, von Weissenberg K (eds), Resistance to Diseases and Pests in Forest Trees: Proceedings of the Third International Workshop on the Genetics of Host-Parasite Interactions in Forestry, 14-21 September 1982, Wageningen. Wageningen: Pudoc. pp 283-287.

Dwinell LD, Barrows-Broaddus J, Kuhlman EG. 1985. Pitch canker: a disease complex of southern pines. Plant Disease 69: 270-276.

Dwinell DL, Fraedrich SW. 1999. Contamination of pine seeds by the pitch canker fungus. In: Landis TD, Barnett JP (tech. coords), National Proceedings: Forest and Conservation Nursery Associations - 1998. Asheville, North Carolina: US Department of Agriculture, Forest Service, Southern Research Station. pp 41-42.

Dwinell LD, Phelps WR. 1977. Pitch canker of slash pine in Florida. Journal of Forestry 75: 488-489.

Dwinell LD, Ryan PL, Khulman EG. 1977. Pitch canker of loblolly pine in seed orchards. In: Proceedings of the Fourteenth Southern Forest Tree Improvement Conference, 14-16 June 1977, Gainsville, Florida. pp 130-137.

EMPPO (European and Mediterranean Plant Protection Organization). 2005. Data sheets on quarantine pests: Gibberella circinata. EPPO Bulletin 35: 383-386.

Fisher RF, Garbett WS, Underhill EM. 1981. Effects of fertilization on healthy and pitch canker-infected pines. Southern Journal of Applied Forestry 5: 77-79.

Frampton JF, Li B, Goldfarb B. 2000. Early field growth of loblolly pine rooted cuttings and seedlings. Southern Journal of Applied Forestry 24: 98-105.

FSC (Forest Stewardship Council). 2002. Chemical pesticides in certified forests: interpretation of the FSC principals and criteria. FSC-IP-0001. Oaxaco: FSC.

Galpare WJ, Hodge GR, Dvorak WS. 2001. Genetic parameters and provenance variation of Pinus maximinoi in Brazil, Colombia and South Africa. Forest Genetics 8: 159-170.

Gebeyehu S, Wingfield MJ. 2003. Pine weevil Pissodes nemorensis: threat to South African pine plantations and options for control. South African Journal of Science 99: 531-536.

Gerhold HD. 1970. A decade of progress in breeding diseaseresistant forest trees. Unasylva 24: 37-44.

Gordon TR, Storer AJ, Wood DL. 2001. The pitch canker epidemic in California. Plant Disease 85: 1128-1139.

Gordon T, Wikler K, Clark S, Storer A, Bonello P. 1999. Resistance to pitch canker in Monterey pine: current and potential impacts of the pitch canker in radata pine. In: Devey ME, Matheson AC Gordon TR (eds), Current and Potential Impacts of the Pitch Canker in Radiata Pine: Proceedings of the IMPACT Monterey Workshop, Monterey, California, 30 November to 3 December 1998. Canberra: CSIRO. pp 87-89.

Guerra-Santos J. 1999. Pitch canker in Monterey pine in Mexico: current and potential impacts of the pitch canker in radata pine. In: Devey ME, Matheson AC, Gordon TR (eds), Current and Potential Impacts of the Pitch Canker in Radiata Pine: Proceedings of the IMPACT Monterey Workshop, Monterey, California, 30 November to 3 December 1998. Canberra: CSIRO. pp 58-61.

Hammerbacher A. 2005. Biology and epidemiology of Fusarium circinatum. MSc (Agric) thesis, University of Pretoria, South Africa.

Hepting GH, Roth ER. 1946. Pitch canker, a new disease of some southern pines. Journal of Forestry 44: 742-744.

Hodge GR, Dvorak WS. 2000. Differential responses of Central American and Mexican pine species and Pinus radiata to infection by the pitch canker fungus. New Forests 19: 241-258.

Hodge GH, Dvorak WS. 2007. Variation in pitch canker resistance among provenances of Pinus patula and Pinus tecunumanii from Mexico and Central America. New Forests 33: 193-206.

Hoefnagels MH, Linderman RG. 1999. Biological suppression of seed-borne Fusarium spp. during cold stratification of Douglas-fir seeds. Plant Disease 83: 845-852.

Hurley B, Govender P, Coutinho TA, Wingfield BD, Wingfield MJ. 2007. Fungus gnats and other Diptera in South African forestry nurseries and their possible association with the pitch canker fungus. South African Journal of Science 103: 43-46.

James RL, Dumroese RK, Wenny DL. 1995. Botrytis cinerea carried by adult fungus gnats (Diptera: Sciaridae) in container nurseries. Tree Planters' Notes 46: 48-53.

James RL, Dumroese RK, Wenny DL, Myers JF, Gilligan CJ. 1987. Epidemiology of Fusarium on containerized Douglas-fir seedlings 1. Seed and seedling infection, symptom production, and disease progression. Report no. 87-13. Missoula: US Department of Agriculture, Forest Service, Northern Region.

James RL, Gilligan CJ. 1984. Studies of Fusarium associated with containerized conifer seedling diseases: pathonegicity tests of isolates from the Alpine Nursery, Kalispell, Montana. Report no. 84-14. Missoula: US Department of Agriculture, Forest Service, Northern Region.

James RL, Perez R, Dumroese RK, Wenny DL. 1999. Virulence of Fusarium oxysporum on Douglas fir germinants: comparison of isolates from nursery soils and roots of healthy and diseased seedlings. In: Lija A, Sutherland JR (eds), Diseases and Insects in Forest Nurseries: Proceedings of the 4th meeting of IUFRO Working Party 7.03.04, 25-28 July 1999, Suonenjoki, Finland. Suonenjoki: Finnish Forest Research Institute. p 14 (abstract only). James RL, Wollen RL. 1989. An evaluation of the efficacy of hot water-chemical treatments to clean styroblock containers, Champion Timberlands Nursery, Plains, Montana. Report no. 89-5. Missoula: US Department of Agriculture, Forest Service, Northern Region

Kietzka JE. 1988. Pinus maximinoi: a promising species in South Africa. South African Forestry Journal 145: 33-38.

Kobayashi T, Muramoto M. 1989. Pitch canker of Pinus luchuensis, a new disease of Japanese forests. Forest Pests 38: 169-173.

Malan FS. 1993. The wood properties and qualities of three South African-grown eucalypt hybrids. South African Forestry Journal 167: 35-44. 
Malan F. 1994. The quality and wood properties of 4 provenances of South-African-grown Pinus tecunumanii. Annals of Forest Science 51: 203-212.

Malan FS. 2003. The wood properties of South African timber resource for high-value solid wood products and its role in sustainable forestry. Southern African Forestry Journal 198: 53-62.

Malan FS. 2006. The wood properties and sawn-board quality of South African-grown Pinus maximinoi (HE Moore). Southern African Forestry Journal 208: 39-47.

McCain AH, Koehler CS, Tjosvold SA. 1987. Pitch canker threatens California pines. California Agriculture 41: 22-23.

McNamara L. 2006. Nutrient concentration of inner bark tissue in pine trees in Mpumalanga in relation to baboon damage. MSc thesis, University of the Witwatersrand, South Africa.

Mitchell RG. 2005. Factors affecting the successful deployment of Pinus patula as rooted cuttings. MSc thesis, University of KwaZulu-Natal, Pietermaritzburg, South Africa.

Mitchell RG, Hongwane P, Olivier R. 2009. Pitch canker outbreak on mature Pinus patula at Roburnia. Unpublished internal research report 4/2009. Sabie: Komatiland Forests.

Mitchell RG, Zwolinski J, Jones NB, Coutinho TA. 2004. The effect of applying prophylactic measures on the post-planting survival of Pinus patula in South Africa. Southern African Forestry Journal 200: $51-58$.

Morris A. 1990. Harvesting slash, Hylastes angustatus and climate as factors influencing transplant survival. Forest Research Document 9/90. Mbabane: Usutu Pulp Company.

Morris A. 1991. Recommendations to improve transplant survival for re-establishment in the Usutu forest. Forest Research Document 3/91. Mbabane: Usutu Pulp Company.

Morris A. 2010. South African Pitch Canker Control Programme. Unpublished progress report to Forestry South Africa.

Muramoto M, Tashiro T, Minamihashi H. 1993. Distribution in Kagoshima prefecture and pathogenicity to pines of Fusarium moniliforme var. subglutinans. Journal of the Japanese Forestry Society 75: 1-9

Nel A, Kanzler A, Dvorak W. 2006. Development of a commercial breeding program for Pinus tecunumanii in South Africa. In: Isik F (ed.), Proceedings of the IUFRO Division 2 Joint Conference: Low Input Breeding and Genetic Conservation of Forest Tree Species, 9-13 October 2006, Antalya, Turkey. pp 160-163.

Nel B, Steinberg C, Labuschagne N, Viljoen A. 2007. Evaluation of fungicides and sterilants for potential application in the management of Fusarium wilt of banana. Crop Protection 26: 697-705.

Newman S. 2004. Disinfecting water for disease management. Paper presented at the 20th Annual Conference on Pest Management on Ornamentals, 20-22 February 2004, San Jose, California.

Nierenberg HI, O’Donnell K. 1998. New Fusarium species and combinations within the Gibberella fujikuroi species complex. Mycologia 90: 434-458.

Ordentlich A, Migheli Q, Chet I. 1991. Biological control activity of three Tricoderma isolates against Fusarium wilts of cotton and muskmelon and lack of correlation with their lytic enzymes. Phytopathology 133: 177-186.

PFWG (Pine Fusarium Working Group). 2004. Forestry takes bold steps towards combating Fusarium circinatum. Wood Southern Africa and Timber Times 30(1): 28

Power AB, Dodd RS, Libby WJ. 1994. Effects of hedging on maturation in radiata pine: western gall rust susceptibility. Silvae Genetica 43: 1-7.

Price RA, Liston A, Strauss S. 1998. Phylogeny and systematics of Pinus. In: Richardson DM (ed.), Ecology and Biogeography of Pinus. Cambridge: Cambridge University Press. pp 49-68.

Rockwood DL, Blakeslee GM, Lowerts GA, Underhill EM, Oak SW.
1988. Genetic strategies for reducing pitch canker incidence in Slash pine. Southern Journal of Applied Forestry 12: 28-32.

Rolando CA, Allan R. 2004. Survival and growth of $P$. patula at two years in response to harvest residue and pest management. Southern African Forestry Journal 200: 19-26.

Roux J, Elsenberg B, Kanzler A, Nel A, Coetzee V, Kietzka E, Wingfield MJ. 2007. Testing of selected South African Pinus hybrids and families for tolerance to the pitch canker pathogen, Fusarium circinatum. New Forests 33: 109-123.

Sakamoto JM, Gordon TR. 2006. Factors influencing the infection of mechanical wounds by Fusarium circinatum on Monterey pines (Pinus radiata). Plant Pathology 55: 130-136.

Schweigkofler W, O'Donnell K, Garbelotto M. 2004. Detection and quantification of airborne conidia of Fusarium circinatum, the causal agent of pine pitch canker, from two California sites by using a real-time PCR approach combined with a simple spore trapping method. Applied and Environmental Microbiology 70: 3512-3520

Smith H, Wingfield MJ, Coutinho TA. 2002. The role of latent Sphaeropsis sapinea infections in post hail associated die-back of Pinus patula. Forest Ecology and Management 164: 177-184.

Sneh B, Agami O, Baker R. 1985. Biological control of Fusarium-wilt in carnation with Serratia liquefaciens and Hafnia alvei isolated from rhizophere of carnation. Phytopathology 113: 271-276.

Staub T, Sozzi D. 1984. Fungicide resistance: a continuing challenge. Plant Disease 68: 1026-1031.

Storer AJ, Bonello P, Gordon TR, Wood DL. 1999. Evidence of resistance to the pitch canker pathogen (Fusarium circinatum) in native stands of Monterey pine (Pinus radiata). Forest Science 45: 500-505.

Storer AJ, Gordon TR, Clark SL. 1998. Association of the pitch canker fungus, Fusarium subglutinans f. sp. pini, with Monterey pine seeds and seedlings in California. Plant Pathology 47: 649-656.

Storer AJ, Wood DL, Gordon TR, Libby WJ. 2001. Restoring native Monterey pine forests. Journal of Forestry 99: 14-18.

Sylvia DM, Sinclair WA. 1983. Suppressive influence of Laccaria laccata on Fusarium oxysporum and on Douglas-fir seedlings. Phytopathology 73: 384-389.

van Heerden SW, Amerson HV, Wingfield BD, Wingfield MJ. 2005 Relative pathogenicity of Cryphonectria cubensis on Eucalyptus clones differing in their response to $C$. cubensis. Plant Disease 89: 659-662.

van Zyl LM, Wingfield MJ. 1999. Wound response of Eucalyptus clones after inoculation with Cryphonectria cubensis. European Journal of Forest Pathology 29: 161-167.

Viljoen A, Marasas WFO, Wingfield MJ, Viljoen CD. 1997. Characterization of Fusarium subglutinans f. sp. pini causing root disease of Pinus patula seedlings in South Africa. Mycological Research 101: 437-445.

Viljoen A, Wingfield MJ, Kemp GH, Marasas WFO. 1995. Susceptibility of pines to the pitch canker fungus Fusarium subglutinans f. sp. pini. Plant Pathology 44: 877-882.

Viljoen A, Wingfield MJ, Marasas WFO. 1994. First report of Fusarium subglutinans f. sp. pini on pines seedlings in South Africa. Plant Disease 78: 309-312.

Vogler D, Kinloch B. 1999. Variation in the radiata pine - western gall rust pathosystem: natural vs controlled inoculations. In: Devey ME, Matheson AC, Gordon TR (eds), Current and Potential Impacts of Pitch Canker in Radiata Pine: Proceedings of the IMPACT Monterey Workshop, Monterey, California, 30 November to 3 December 1998. Canberra: CSIRO. pp 98-99.

Wilkinson RC, Underhill EM, McGraw JR, Pritchett WL, Schmidt RA. 1977. Pitch canker incidence and fertilizer-insecticide treatment. IFAS Progress Report 77-1. Gainesville: Institute of Food and Agricultural Sciences, University of Florida.

Wingfield MJ. 1999. Pathogens in exotic plantation forestry. International Forestry Review 1: 163-168. 
Wingfield MJ, Coutinho TA, Roux J, Wingfield BD. 2002a. The future of exotic plantation forestry in the Southern Hemisphere: lessons learnt from pitch canker. Southern African Forestry Journal 195: 79-82.

Wingfield MJ, Hammerbacher A, Ganley RJ, Steenkamp ET, Gordon TR, Wingfield BD, Coutinho TA. 2008. Pitch canker caused by Fusarium circinatum - a growing threat to pine plantations and forests worldwide. Australasian Plant Pathology 37: 319-334.

Wingfield MJ, Jacobs A, Coutinho TA, Ahumada R, Wingfield BD. 2002b. First report of the pitch canker fungus, Fusarium circinatum, on pines in Chile. Plant Pathology 51: 397.
Wingfield MJ, Roux J, Coutinho TA, Govender P, Wingfield BD. 2001. Plantation disease and pest management in the next century. Southern African Forestry Journal 190: 67-71.

Wingfield MJ, Wingfield BD, Coutinho TA, Viljoen A, Britz $H$, Steenkamp ET. 1999. Pitch canker: a South African perspective. In: Devey ME, Matheson AC, Gordon TR (eds), Current and Potential Impacts of Pitch Canker in Radiata Pine: Proceedings of the IMPACT Monterey Workshop, Monterey, California, 30 November to 3 December 1998. Canberra: CSIRO. pp 62-69.

Zagory D, Libby WJ. 1985. Maturation-related resistance of Pinus radiata to western gall rust. Phytopathology 75: 1443-1447. 